\title{
Merton and Ziman's modes of science: the case of biological and similar material transfer agreements
}

\author{
Victor Rodriguez
}

\begin{abstract}
This paper makes a connection between recent studies on research materials exchange and its effect on the progress of science. Academia fears that scientific development could be hampered by the privatised practices of research material exchange. Since post-academic science represents a sufficient departure from the prior state of the knowledge production system as to open-science assumptions, this paper argues that the current use of Mertonian norms as a basic hypothesis can be considered inappropriate in the new privatised science firmament.
\end{abstract}

$\mathrm{P}$ OLICY DEBATES ABOUT the progress of life sciences have been focused on the welfare effects of restricted access to research materials, broadly defined to include cell lines, monoclonal antibodies, reagents, animal models, combinatorial chemistry libraries, clones and cloning tools, databases, and software under some circumstances. One way to gain access to research materials is through material transfer agreements (MTAs).

Triono Soendoro, Director General of Indonesia's National Institute of Health Research and Development, revealed that Indonesia stopped sharing its bird flu samples with the World Health Organisation after CSL, an Australian drug-maker, developed and tried to market a vaccine using the Indonesian strain of the virus without the Indonesian Health Ministry's consent. Soendoro said that several Indonesian laws regulate that each virus specimen that Indonesia

\footnotetext{
Victor Rodriguez is in the Department of Managerial Economics, Strategy and Innovation, Katholieke Universiteit Leuven, Naamsestraat 69, B-3000 Leuven, Belgium; Email: victor. rodriguez@econ.kuleuven.be.

The author is grateful to Peter Collins from the Royal Society, Kate Hoye from Ottawa University, Ivo Roelants from Katholieke Universiteit Leuven Research and Development, Susana Borrás and the two anonymous referees of Science and Public Policy for their fruitful comments. Special thanks go to Tom Howes and Nicholas Neill-Fraser for editing the final manuscript.
}

sends abroad should be accompanied by an MTA. The agreement stipulates that the permission of the sending party is required if the sample is to be developed for commercial purposes. However, when bird flu broke out in 2005, the MTA was scrapped in order to make sample sharing easier. Since then, every sample transfer was done based only on the trust that nobody would violate the MTA (Soedarjo, 2007).

MTAs formalise the exchange of research material between a provider and a receiver for research purposes. Unlike patents or copyrights, MTAs do not rest on codified legal statutes defining specific rights and obligations. Instead, reflecting freedom of contract, parties have wide discretion in setting the terms of their agreements and tailoring them to their specific needs. MTAs' provisions may vary depending on the intention of the parties. They may stipulate payment for using the material. They generally impose prepublication review, disclosure restrictions, liability indemnification, or restriction on actual use. They often extend reach-through or grant-back provisions.

Those MTA clauses have generated concern about limiting academic freedom and so influencing the progress of science - the thesis. The restriction might be caused by constraining the choice of research agendas because of the lack of research materials. Another restriction might be the absence of recipients' freedom to continue a line of research 
Victor Rodriguez is a researcher in the Department of Managerial Economics, Strategy and Innovation at the Katholieke Universiteit Leuven in Belgium. His main research interests are in the economics of science and innovation policy. His projects in Leuven deal with material transfer agreements in biotechnology. He has contributed articles to: The Journal of World Intellectual Property; Nature Biotechnology; BNA's Patent, Trademark and Copyright Journal; Scientometrics; Les Nouvelles; Technology in Society; and Research Evaluation, among others. Previously, he was a visiting scholar at the University of Ottawa and the Conference Board of Canada. He also carried out research at the American Enterprise Institute in the United States of America.

because they no longer own their inventions made through the use of the material. Finally, delays in publishing, or refusal to publish, research results that have used the received material might hamper research agendas.

A review of recent empirical literature shows that the concern as to whether MTAs affect the progress of science (Rodriguez, 2005) has been translated into testable hypotheses for life sciences (Campbell et al, 2002; Walsh et al, 2005; Rodriguez et al, 2007). A recent study found that MTAs did not affect the research agenda choice in such a way as to impede the progress of biotechnology (Rodriguez et al, 2007). These findings have prompted the most likely explanation that science itself adapted perfectly to the commercialisation - the antithesis by means of Zimanian norms.

Substantial research effort has been devoted to co-operative relationships between firms and universities (Mora-Valentin, 2002), commercialisation of biotechnology (Enzing et al, 2004) and transdisciplinarity (Adam et al, 2006). However, there has been little analysis of the gift and market model applied to MTAs.

In this paper, I consider that the concern of academia that scientific development could be hampered by privatised practices in research material exchange, formalised through MTAs, has been formulated following Mertonian norms. Since post-academic science represented a sufficiently significant departure from the prior state of the knowledge production system as to open-science assumptions, I argue that the current use of the Mertonian norms can be considered inappropriate for framing scholarly studies on post-academic science.

The rest of the paper is organised as follows. To begin with, the Mertonian and Zimanian norms are distinguished in order to contextualise the arguments. Then, the privatisation of scientific knowledge is examined to understand the departure of the gift model. After that, the functions of science are portrayed to show how MTAs as an instrumental tool generated collision with non-instrumental roles of science. In the next section, the research agenda choice hypothesis is falsified by the evidence given. Finally, I conclude by synthesising accounts between the thesis and antithesis.

\section{Mertonian norms}

In this section, I consider how Mertonian norms helped explain material exchange in academic science. In the past, academic science was the stereotype of science in its purest form. Academic scientific behaviour was characterised by a particular ethos, described in the Mertonian norms of communism, universalism, disinterestedness, and organised scepticism (Merton, 1973). Merton saw them as the rules of the game of doing science, embodied in the social conventions and practice of science (Ziman, 1999).

Communism, sometimes communalism as a euphemism, referred to the common ownership of scientific discoveries, according to which scientists gave up intellectual property rights in exchange for recognition and esteem — the gift model. Thereby the results of science were public and free for anyone to use. In other words, academic scientists must publish articles in academic journals or perished. Universalism indicated that the veracity of claims was evaluated in terms of universal or impersonal criteria, and not on the basis of race, class, gender, religion, or nationality. That science was a career open to talented people is another way of saying universalism.

Disinterestedness represented scientists that sought new knowledge for its own sake rather than seeking to further their own interests. Academic scientists that did not benefit from royalties or equity can be considered disinterested. Finally, organised scepticism meant that the scientific community subjected the claims of its members to peer review.

Academic science was studied by several scholars. The market failure theory of science was developed by Nelson (1959) and Arrow (1962). They stressed that specific characteristics of knowledge result in a default in knowledge creation incentives. Consequently, the level of private investment in knowledge creation was below its optimal level, a situation that justified public support of basic research in academia.

A significant number of scholars shaped by Merton's norms have articulated their writings to describe or explain academic science (for instance, Dasgupta and David, 1994; Stephan, 1996). Dasgupta and David (1994) synthesised Merton's mechanisms at play within academia in an economic fashion. They highlighted that its functioning had two fundamental and original economic properties. First, it avoided some of the asymmetricinformational problems that might have otherwise arisen between government agencies that support the research and scientists during the public procurement of scientific knowledge. Second, since the action of disclosing knowledge was the incentive, the reward system created simultaneous incentives for knowledge creation and dissemination within the academic community.

Historically, research materials were freely exchanged, without formal arrangements. Academic scientists participated in a gift economy, a system of 
material exchange premised on reciprocity, reputation and responsibility. Research materials were made available in exchange for credit. Academic scientists were supposed to transfer research materials for honour and the academic system of exchange was supposed to be based on the reciprocity and personalised exchange of gifts (Mauss, 1967).

Through the quality and generosity of giving, receiving and repaying, academic scientists demonstrated authority. As a mark of obligations, gifts remain bound up with the donor, such that the donor's identity worked to animate the gift. Research materials were sent out into the world to bring an equivalent gift back to the donor. Once transferred, research material can gain recognition and status for the donor and, the more recognition the gift received, the greater the value of the original and subsequent gifts (Hagstrom, 1965).

\section{Zimanian norms}

In this section, I offer an argument to discard the use of Mertonian norms in post-academic exchange of research materials. From the beginning of the Cold War, academic science began deviating more and more from the long-established mode. This change was accelerated after the Bayh-Dole Act in the USA in 1980. Most European countries, except for Sweden, mirrored the Bayh-Dole Act to allow universities to become the owner of patents for inventions made by their employees according to certain conditions. Universities have the obligation to give a fair return to inventors through royalties or equity. In this manner, the privatisation of academic science subverted the social order of academia and postacademic ethos emerged, the counter-Mertonian norms.

Ziman (2000) gave the emerging system the name post-academic science, which is the term I will use here. What is changing is the definition of science itself: the new regime shows that the idealised picture of academic science no longer holds. The term post-academic science suggests that science now fits neither the academic nor the industrial model. Nowadays, science may be characterised as being

\section{The term post-academic science} suggests that science now fits neither the academic nor the industrial model: nowadays, science may be characterised as being proprietary, local, authoritarian, commissioned and expert proprietary, local, authoritarian, commissioned and expert (Ziman, 2000).

Proprietary means exclusive ownership of knowledge - the market model. Local indicates that knowledge is primarily created to solve practical problems. Authoritarian designates research that is hierarchically managed. Commissioned represents research based on external commissions aiming at practical utility. Expert symbolises a researcher that is a paid problem solver.

Empirical evidence of this change can be found in new social practices and conventions in academia, such as entrepreneurial universities, academic spinoffs, consultancy functions of professors, recruitment of $\mathrm{PhD}$ candidates or post-docs to develop research lines already set up by sponsors, intellectual property rights, licensing, project proposals and grants, directed programmes, university-industry collaborations, global networks, interdisciplinary centres and teams, research performance evaluations and so on. Accordingly, the creation of new research networks and communities of a hybrid kind at university departments became prominent.

In 1993, for the first time, the Association of University Technology Managers (AUTM) in the USA began to rank institutions by patent income, that is, not only in terms of the number of patents per university but also according to the total revenue generated from these. The intensified privatisation was also reflected in the rhetoric uses of the National Science Foundation (NSF) in the USA producing glossy reports reminiscent of those of corporations (Slaughter and Rhoades, 1996).

What originally was a duopoly ${ }^{1}$ in science, traditional disciplinary communities and hybrid research communities, turned into a monopoly. So, the old autonomy mode of knowledge production was discarded and replaced by organisational, administrative and budgetary steering mechanisms in academia. Thus, universities turned into hotels where externally funded project researchers booked in from time to time, while the universities supplied the towels, soap and what-have-you (Price, 1967). In addition, externally funded project researchers assumed no responsibility for undergraduate teaching or graduate training.

While providing access to materials not available within the organisation, MTAs might threaten control over research material, erode scientific or technological leads, accelerate the dissemination of undesired results, exhaust time for patent negotiation or cause disputes over intellectual property rights relating to the exchanged material.

To avoid disputes over control of the provided materials, MTAs may contain a broad definition of the material, including not only the original material but also the progeny, the unmodified derivatives, and even confidential information related to the material. The progeny is the unmodified descendant from the original materials, such as virus from virus, cell from cell, or organism from organism. The unmodified 
derivatives are substances created by the recipient that constitute an unmodified functional subunit or product expressed by the original material, such as subclones of unmodified cell lines, monoclonal antibodies secreted by a hybridoma cell line, or purified or fractionated subsets of the original material.

A grant-back clause aims to protect the provider's competitive position in the event that the recipient of the material obtains a patent or makes a related invention. Although the obligation to negotiate royalties thus applies only to inventions derived directly from the transferred material, some agreements attempt to 'reach through' and secure royalties on a broader category of products. These provisions have given rise to concerns under competition law, arising from fears that they may be used to extend a provider's dominant market position.

Controlling material distribution, limiting its use in a laboratory, and ensuring return of unused materials are critical to maintaining the provider's competitive edge. The materials should only be used at the recipient's organisation and under direct supervision of the scientist's laboratory. The materials should not be transferred to anyone else within the recipient's organisation.

MTAs frequently include provisions designed to prevent access to the material by third parties, so as to make sure that the material does not reach parties not bound by the confidentiality commitments. Such provisions may, for instance, require the recipient to separate research activities on the transferred material from other research and to introduce control procedures to restrict the number of staff that will have access to it.

If patents are expected to result from research on the transferred material, MTAs may stipulate that the receiver's publications of research based on the material must be deferred for a stated period of time so that patent rights can be obtain in the interim. The agreement may also require parties to report to each other on any actions they may take with respect to patents so as to protect their mutual rights to royalties, and to facilitate patent applications in case the non-patenting party has information needed in the application.

Difficulties may arise when an investigator uses two materials from two different providers. In such a situation, it is quite likely that the terms of the agreement covering the two materials will be incompatible. This type of conflict should be avoided. Thus, providers often require investigators and their organisations to state in their agreements that no such conflicts currently exist and that none will be allowed to develop.

Since the provider of the material does not usually fund the research project of the receiver, the receiver needs to ensure that its intellectual property obligations to those sponsors who do fund the work do not conflict with the proposed obligations to the provider of the material. Because so much research is externally funded, it may be important to acknowledge clearly in the MTA the rights of the financial supplier regarding inventions that may be made with the material.

An agreement term may require that the recipient indemnify the provider against any damage that occurs through use of the material, implying that the provider is not responsible even if the material was provided without proper warnings as to associated hazards or needed precautions. Some materials are in fact hazardous to the user, and recipients tend to require that such hazards be disclosed and that the provider take responsibility for negligence in disclosure of known hazards. Such requirements aim to maintain safety of employees, not all of whom may be equally knowledgeable about hazards.

To avoid the dissemination of undesired results, limitations may be imposed on the recipient's publication of their research results without the provider's approval. The purpose of such a restriction is to allow the provider to determine whether its own confidential information has been improperly disclosed in the manuscript or presentation, and whether new intellectual property may have arisen from use of the materials that the provider wants to protect. Even if such a provision is framed in equitable language, the recipient investigators will need to decide whether they can comply with such a restriction and, if not, the agreement should not be signed.

\section{Market model}

The proprietary claiming wave or market model has been the consequence of high levels of investment in research and development (R\&D) and extraordinary scientific and technological breakthroughs. Even though MTAs provide a safeguard for investments in technology by setting out the conditions for using the material, the open science or gift model is limited by MTAs (Rodriguez, 2005). In this section, I portray the market model that is featuring postacademic exchange of research materials.

Nothing could be more central to an understanding of post-academic science than the privatisation of research results. Historically, basic science meant knowledge directed solely toward expanding human knowledge, while applied science meant knowledge directed toward solving practical problems. Thereby, the operation of privatising knowledge through the patent system was confined to applied science and has never been under question. Nowadays, basic science can be privatised and applied science can fail to meet the requirements to be privatised through intellectual property rights.

Basic science can currently be patented if certain legal requirements are met. In genomics, patents were granted quite early for naturally occurring proteins and the genes that coded them. Not long ago, the sequencing of genes was difficult and often took place together with the identification and purification of the protein. The patent law's requirement of novelty was 
met by taking into account that the product had never existed in an isolated form, and that the gene sequence had never before been isolated. Although protection of the protein does not necessarily imply protection of the sequence, sequence claims were regularly granted (Barton, 2001).

Not all applied research results can be privatised. Rees (2000) proposed considering the possibility of subjecting patient-oriented science ${ }^{2}$ to intellectual property rights to foster its development. He argued that applied research, such as Breslow's technique of measuring melanoma prognosis by assessing depth or Gottlieb's delineation of the AIDS (acquired immune deficiency syndrome) diagnosis, should be patentable in the same way that kits for measuring melanoma markers or HIV (human immunodeficiency virus) load are. He thought that such a shift would generate the injection of resources needed to revive clinical science.

The revolution in molecular genetics enabled investigators to produce molecules with medicinal properties. Academic researchers joined venture capitalists in founding the biotechnology industry. The participation of prominent scientists in the fist biotechnology companies reversed the perception that academicians' involvement in business activities was unsavoury or evidence of intellectual bankruptcy. Nor were financially bankrupt university researchers receiving research support and profiting personally from their discoveries, although the value to society of the products far exceed any individuals' accrual of wealth.

Proprietary claims have reached further upstream from end products to cover fundamental discoveries that provide the knowledge base for future product development. One important reason for this change is a narrowing of the conceptual gap between fundamental research and commercial application, especially in biotechnology.

Once largely a matter of serendipity or trial-anderror, biotechnology is now critically dependent on basic knowledge of genes, proteins and associated biochemical pathways. It has the potential to produce plenty of breakthroughs in existing industries such as agriculture, food-processing and human health. As one commentator noted: "[t]his is the first time that science is the actual business” (Pisano, 2002).

The foreseeable practical payoffs of this type of fundamental research make it easier to obtain patents for discoveries that, in an earlier era, would have seemed too far removed from useful applications for patent protection. As these advances in human understanding have become patentable, new firms have emerged, raising capital to develop and market proprietary research that lies somewhere between traditional academic research and end-product development.

The earliest breakthroughs in biotechnology, such as the Harvard OncoMouse, ${ }^{3}$ were not downstream products aiming at a consumer market. However, the US Patent and Trademark Office reinforced the

\section{Repeated granting of reach-through provisions would be chaotic; a receiver cannot promise an exclusive licence to future discoveries more than once in the course of a research project before creating multiple conflicting obligations}

trend toward privatisation of upstream research by expanding the jurisdiction of the patent system.

Thus, it became possible for technology managers to capture more of the potential revenue stream by adding reach-through provisions to the patent claim. Because reach-through provisions on patents proved too slow and uncertain for privatising research, the biotechnology sector created MTAs. Although pioneered by industry, government and academia have made increasing use of MTAs. Technology transfer offices processed nearly 500 MTAs at the University of Pennsylvania in 1999 (Enserink, 1999) and 2,000 at the University of California in 2002 (Streitz et al, 2003).

The post-academic convergence of basic science and applied science created the controversy in privatising research results. One of the main arguments against patenting results from basic research was the inability of researchers to use that privatised knowledge in their own research. This situation was described as the "tragedy of anticommons" (Heller and Eisenberg, 1998) in reference to an earlier description of the degradation of the property rights/natural environments as the tragedy of commons.

The tragedy of the anticommons helps explain why people underuse scarce resources such as research materials. In this hypothesis, MTA restrictions and reach-through provisions can be so onerous that negotiations over research materials become prohibitively complex and expensive, with science held hostage to a phalanx of intellectual property managers (Mirowski and van Horn, 2005).

In particular, questions of interpretation arise, requiring inferences, parallels, extrapolations and other logic solutions that could be harmful for both the owners and users of research tools. Repeated granting of reach-through provisions would be chaotic; a receiver cannot promise an exclusive licence to future discoveries more than once in the course of a research project before creating multiple conflicting obligations (Eisenberg, 2001).

\section{Functions of science}

In this section, I focus on the collision of instrumental and non-instrumental roles of science when using 
MTAs. For Ziman (2003), science was treated as an instrument of policy, serving the material interests of government and commerce. As policies cost money, they are most easily justified if they can be made to appear profitable. Their impact is best appreciated if it can be quantified. In this context, policy-makers value science primarily as a mode of wealth creation, contributing to the economic competitiveness.

The motives used for the Bayh-Dole Act or the Lisbon European Council goals can illustrate the instrumental roles given to science. First, by the early 1970s, the USA began to lose its technological advantage as noted by Bayh (2006): the number of US patents issued each year had declined steadily since 1971, from 1973-1978 the number of patents granted to non-US citizens increased 35\%, investment in R\&D over the previous ten years had been dormant, US productivity was growing at a much slower rate than that of competitors and small businesses that had provided most of the new jobs were receiving a smaller percentage of federal funding for R\&D. Second, in a different time and space, analogue grounds have motivated the Lisbon strategy that wants to make the European Union the most competitive and dynamic knowledge-based economy, capable of sustainable economic growth with more and better jobs and greater social cohesion (European Council, 2000).

Bayh-Dole legislation allowed universities to retain ownership of the ideas they developed through money coming from taxpayers. Universities could license such patented ideas to industry at large for commercialisation and would receive royalties. The post-academic inventors could also receive a share of the royalties if they assisted in developing the patent to market (Bayh, 2006).

Nelson (2004) noted that there is nothing in the Bayh-Dole Act that explicitly encourages exclusive or narrow licensing, but nothing discourages it either, and the rhetoric associated with the legislation pushed the theory that generally dedicating research results to the public commons did not encourage use. He also stated that there is nothing in the legislation that says universities should use their patenting and licensing power to maximise university income, but there is little in the language that discourages it.

In the external validation of a study by Rodriguez et al (2007), 60\% of Belgian interviewees in the field of biotechnology said they had given up projects because they did not have the research materials. Once an MTA is signed, some of its provisions might interfere with academic freedom. Recipients may lose the freedom to continue a line of research because they no longer own their inventions made through the use of the material. They may encounter delays or denial of permission to publish research results using the received material. For publication screening, $90 \%$ of interviewees said there was no instance of an article for publication being rejected because the provider refused their disclosure request;
$60 \%$ said there were no delays in submitting documents for publication because the provider postponed it (Rodriguez et al, 2007).

In a recent court ruling between Washington University and Dr William Catalona (US District Court, 2006), MTAs illustrate the instrumental and noninstrumental functions of science. Dr Catalona is a highly respected urologist and urologic surgeon and a well-established medical researcher of prostate cancer. He was instrumental in establishing a biorepository for the collection and storage of research materials at Washington University. At times, other research institutions have requested samples from the bio-repository for research projects. The transfer of such material was made pursuant to an MTA. At least seven of these MTAs personally signed by Dr Catalona acknowledged Washington University as the owner of the biological samples involved in the case.

Washington University intellectual property policy, in existence prior to the dispute arising, stated that tangible research property, including biological materials, belong to the university if significant university resources were used or such property was obtained pursuant to a research project funded by an external sponsor administered by the university. Furthermore, in all MTAs concerning these materials, including those wherein Dr Catalona was the provider, the university clearly exerted its ownership interest without objection by him. Even in the instance when Dr Catalona attempted to change the language of an MTA to reflect co-ownership with the university, and the university refused to modify the language in the MTA, he still signed. When Dr Catalona moved to another university, he tried to take the tissues with him. Washington University refused, saying that it owned the tissues; the judge upheld the university's position.

Dr Catalona, who is now at Northwestern University's Feinberg School of Medicine in Chicago, says (Silverman, 2007):

I remember that shortly after the Bayh-Dole Act passed, there was one person in a dingy office. We were on a first-name basis and it was very mom-and-pop like. But later, technology transfer had to earn its keep. They had these pressures to close deals and ensure the university got as much as possible. I wanted to get the science done. But they stalled and stalled, and I could not provide the samples. I can see how university rights need to be protected. And somebody has to pay for those employees. But in this case, the university somehow went off the deep end and subordinated the rights of patients to its own interests. I understand this is a very big business for universities, pharmaceutical and biotechnology companies. And I think technology transfer is fine, as long as it does not get in the way of doing science. But for scientists, it is a real conundrum. 
As post-academic scientists faced material incentives, research agendas might have been diverted towards more profitable research topics in instrumental science. Besides, post-academic scientists that benefited from royalties or dividends from equity could not provide an impartial or disinterested opinion (a non-instrumental function) when called in by government officials for scientific advice in their research field.

Since university research results became privatised, the most frequent block to negotiating MTAs is not monetary costs but other terms and conditions of the agreement, such as the provider control of publication. Moreover, a lack of research materials might impede the progress of science by constraining the academic freedom in the pursuit of non-instrumental roles. Finally, access to research materials with unfavourable conditions for academia also limits academic freedom by definition.

\section{So-called academic freedom}

In this section, I depict how MTAs might affect one element of academic freedom, the research agenda choice. One of the foremost constructs in modern science was academic freedom (Bailyn, 1985). Academic freedom not only meant the freedom to choose research agendas, methods or questions, the freedom to communicate research results and the freedom to interpret research results but also indicated the freedom to collaborate in research projects.

External criteria influence the way research problems are posed and focused, and what kind of empirical materials and data are needed. Thus, relevance and accountability pressures can contribute to shifts of problem interest. They are constitutive for new problem formulation and perhaps new modes of assessing research results. Cognitive sociology of science maintains the theory choice and also the very fabric of theory formation may be socially shaped. When external criteria attain a dominant role, the debate about autonomy and academic freedom emerges. Autonomy-talk is symptomatic of strain and possible change (Elzinga, 1997).

On the basis of a Mertonian reconstruction of research agenda choice, Carayol and Dalle (2004) modelled a sequential determination of research agendas and subsequent dynamic knowledge production. Their model was designed to capture two features of the process of collective knowledge creation: the set of problems to be addressed is not fixed and the allocation of research efforts to a set of problems is derived from motivations of scientists. Incentives for performing research on research areas have been highlighted by the empirical literature on problem choice in science. For instance, Debackere and Rappa (1994) and Rappa and Debackere (1993) studied the problem choice by recording, over a long period, scientists' entry choices in an emerging field and by surveying their motivations.
A recent empirical study by Rodriguez et al (2007) found that MTAs did not affect the research agenda choice in such a way as to impede the progress of biotechnology. Research agendas were mapped through patents, articles, letters, reviews and notes. Methodologically, a co-word analysis was performed to detect whether there was a difference in underlying scientific structure. Secondly, interviews with practitioners of industry and government were intended to capture their opinion regarding the impact of the signed agreements on their own research agenda choices. The existence of synchronic and diachronic common terms between co-word clusters, stemming from publications that used MTAs and those that did not, suggested cognitive linkage, which is why the authors cannot conclude that MTAs affected research agenda setting.

If Kitcher (1993) model can be applied, MTAs might not necessarily obstruct scientific progress but might promote it. His model shows that communities of epistemically sullied scientists can perform better than communities of epistemically pure ones. This operation of social systems is modelled in a way that is a standard procedure in economics. Given certain assumptions about the actors' preferences, the constraints of the situation and the behaviour of the agents according to the rationality principle, it is shown that there exists some equilibrium point to which the interaction process converges. This does not mean that this point will necessarily be reached in reality, but it is a possibility.

As in Adam Smith's classical argument, Kitcher shows that the positive consequences of distribution of labour can be found in science as well (Kitcher, 1990). Under specific constraints, scientific progress is fostered, not hindered, by self-interest. Selfinterested researchers are one of the features of postacademic science.

\section{Conclusion}

In this paper, I have maintained that concerns regarding scientific development by privatised practices in research material exchange, formalised through MTAs, were formulated following Mertonian norms. Those concerns resulted from restrictions on publishing research that used research material received through MTAs. Nonetheless, Mertonian norms described practices in the heyday of science as an academic model. Commercial involvement in university research undermines norms governing the sharing of research materials if the gift model is used to study current research practices.

I have also shown how MTAs cross the gift and market boundary. MTAs are allowed to mediate between gift and market model because the two models do not share assumptions. Companies or even universities that license these materials to researchers can force them to sign MTAs that tightly restrict the researchers' use of these materials in the market 
model. For example, many MTAs require researchers to assign or license intellectual property rights to discoveries made in the course of using the research materials. Others prohibit sharing research materials with other researchers or sending these materials to other institutions.

Since post-academic science represents a sufficient departure from the prior state of the knowledge production system as to open-science assumptions, I have argued that the current use of the Mertonian norms can no longer be considered as a theoretical framework for scholarly studies on post-academic science. Empirically, I have given evidence that research practices, such as use of MTAs, have adapted to the market model and that is why no hampering

\section{Notes}

1. The construct 'basic science' was assimilated into traditional disciplinary communities and 'applied science' to hybrid research communities (van den Daele and Weingart, 1976; van den Daele et al, 1977). The 'disciplinary communities' had their loyalties oriented towards the academic system, its career structure, values and preferred mode of knowledge production and procedures for quality control. The 'hybrid communities' tended to be stimulated to put societal relevance criteria to the fore and their loyalties to the institutional motives of the sectoral funding sponsor.

2. Medical research can be classified into three types: basic; disease-oriented; and patient-oriented. Disease-oriented research is defined as research targeted towards the understanding of the pathogenesis or treatment of a disease and may use patient materials such as cultured cell or DNA samples, but not the whole patient. In contrast, patient-oriented research requires direct contact between the patient and the scientist (Goldstein and Brown, 1997).

3. The OncoMouse is a type of laboratory mouse that has been genetically modified using modifications designed by Harvard University and DuPont to carry a specific gene called an activated oncogene. The activated oncogene significantly increased the mouse's susceptibility to cancer and thus makes the mouse suitable for cancer research.

\section{References}

Adam, M, M Carrier and T Wilholt 2006. How to serve the customer and still be truthful: Methodological characteristics of applied research. Science and Public Policy, 33, 435-444.

Arrow, K 1962. Economic welfare and the allocation of resources for invention. In The Rate and Direction of Inventive Activity, ed. R Nelson. Princeton NJ: The Princeton University Press.

Bailyn, L 1985. Autonomy in the industrial R\&D lab. Human Resource Management, 24, 129-146.

Bayh, B 2006. Bayh-Dole: Don't turn back the clock. Les Nouvelles, 41, 215-218.

Barton, J 2001. Patents in genomics and basic research: Issues for global health. Commission on Macroeconomics and Health Working Paper Series. Geneva: World Health Organisation.

Campbell, E, B Clarridge, M Gokhale, L Birenbaum, S Hilgartner, N Holtzman and D Blumenthal 2002. Data withholding in academic genetics: Evidence from a national survey. Journal of the American Medical Association, 287, 473-480.

Carayol, $\mathrm{N}$ and J Dalle 2004. Sequential problem choice and the reward system in open science. Unpublished manuscript.

Dasgupta, P and P David 1994. Toward a new economics of science. Research Policy, 23, 487-521.

Debackere, K and M Rappa 1994. Institutional variations in problem choice and persistence among scientists in an emerging field. Research Policy, 23, 425-441.

Eisenberg, R 2001. Bargaining over the transfer of proprietary effect was found on research agenda choice.

The debate on MTAs as a means of formalising research material exchange should take into consideration Ziman's norms. I have tried to take the bull by the horns by disentangling academic and postacademic approaches in scholarly studies on science and technology by using various lines of argument. This paper may contribute towards a better understanding of the current functioning of science and its governance. It is clear that there are interests other than science for its own sake when transferring research material: the instrumentalism of science. These instrumental objectives fall perfectly within the scope of university or governmental authorities.

research tools. In Expanding the Boundaries of Intellectual Property, eds. R Dreyfuss, D Zimmerman and H First. New York NY: Oxford University Press.

Elzinga, A 1997. From Arrhenius to megascience: Interplay between science and public decisionmaking. Ambio, 26, 72-80.

Enserink, M 1999. NIH proposes rules for materials exchange. Science, 284, 1445.

Enzing, C, A van der Giessen and S Kern 2004. Commercialisation of biotechnology: Do dedicated public policies matter? Science and Public Policy, 31, 371-383.

European Council, 2000. Lisbon European Council: Presidency Conclusions. Brussels: European Council.

Goldstein, J and M Brown 1997. The clinical investigator: bewitched, bothered, and bewildered - but still beloved. Journal of Clinical Investigation, 99, 2803-2812.

Hagstrom, W 1965. The Scientific Community. New York NY: Basic Books.

Heller, M and R Eisenberg 1998. Can patents deter innovation? The anticommons in biomedical research. Science, 280, 698-701.

Kitcher, P 1990. The division of cognitive labor. Journal of Philosophy, 87, 5-22.

Kitcher, P 1993. The Advancement of Science: Science without Legend, Objectivity without Illusions. New York NY: Oxford University Press.

Mauss, M 1967. The Gift: Forms and Functions of Exchange in Archaic Societies. New York NY: Norton and Co.

Merton, R 1973. The Sociology of Science: Theoretical and Empirical Investigations. Chicago IL: University of Chicago Press.

Mirowski $P$ and R Van Horn 2005. The contract research organization and the commercialization of scientific research. Social Studies of Science, 35, 503-548.

Mora-Valentin, E 2002. A theoretical review of co-operative relationships between firms and universities. Science and Public Policy, 29, 37-46.

Nelson, R 1959. The simple economics of basic scientific research. The Journal of Political Economy, 67, 297-306.

Nelson, R 2004. The market economy, and the scientific commons. Research Policy, 33, 455-471.

Pisano, G 2002. Pharmaceutical biotechnology. In Technological Innovation and Economic Performance, eds. R Nelson, D Victor and B Steil. Princeton NJ: Princeton University Press.

Price, D 1967. The Scientific Estate. Cambridge MA: Harvard University Press.

Rappa, M and K Debackere 1993. Social and cognitive influences on problem choice in R\&D. Best Research Paper Proceedings of the American Academy of Management, 53, 347-351.

Rees, J 2000. Patents and intellectual property: a salvation for patient-oriented research? The Lancet, 356, 849-850.

Rodriguez, V 2005. Material transfer agreements: open science vs. proprietary claims. Nature Biotechnology, 23, 489-491.

Rodriguez, V, F Janssens, K Debackere and B De Moor 2007. Do material transfer agreements affect the choice of research agendas? The case of biotechnology in Belgium. Scientometrics, 71, 239-269.

Silverman E 2007. The trouble with tech transfer. The Scientist, 21, 40-45. 
Slaughter, S and G Rhoades 1996. The emergence of a competitiveness research and development policy: Coalition and commercialization of academic science and technology. Science, Technology and Human Values, 23, 303-339.

Soedarjo, A 2007. WHO must follow rules, like everyone else. The Jakarta Post, 17 February.

Stephan, P 1996. The economics of science. Journal of Economic Literature, 34, 1199-1235.

Streitz, W, I De Bear, C Calmettes and F Reinhart 2003. Material Transfer Agreements: a Win-Win for Academia and Industry. Northbrook IL: Association of University Technology Managers.

US District Court for the Eastern District of Missouri, Eastern Division 2006. The Washington University v. Dr William Catalona and his patients. Case no 4:03CV1065SNL. Lexis, 22969, 1-93.

van den Daele, W and P Weingart 1976. Resistance and receptivity in science to external direction: the emergence of new disciplines under the impact of policy. In Perspectives on the Emergence of Scientific Disciplines, eds. G Lemaine, R MacLeod, M Mulkay and P Weingart. The Hague: Mouton.

van den Daele, W, W Krohn and P Weingart 1977. The political direction of scientific development. In The social Production of Knowledge: Sociology of the Sciences Yearbook, eds. E Mendelsohn, P Weingart and R Whitle. Dordrecht: Reide.

Walsh, J, C Cho and W Cohen 2005. View from the bench: Patents and material transfers. Science, 309, 2002-2003.

Ziman, J 1999. Rules of the game of doing science. Nature, 400, 721.

Ziman, J 2000. Real Science: What it Is and What it Means. Cambridge: Cambridge University Press.

Ziman, J 2003. Non-instrumental roles of science. Science and Engineering Ethics, 9, 17-27. 